GRASAS Y ACEITES 69 (1)

January-March 2018, e243

ISSN-L: 0017-3495

https://doi.org/10.3989/gya.1104172

\title{
In vivo correlation of olive leaves extract on some oxidative stress markers in streptozotocin-induced diabetes mellitus in rats
}

\author{
A.M.R. Afify, H.S. El-Beltagi ${ }^{\bowtie}$, S.A. Fayed and A.E. El-Ansary \\ Biochemistry Dept, Faculty of Agriculture, Cairo University, P.O. 12613, Gamma st., Giza, Cairo- Egypt. \\ $\bowtie$ Corresponding author: helbeltagi@agr.cu.edu.eg
}

Submitted: 25 October 2017; Accepted: 19 December 2017

\begin{abstract}
SUMMARY: Diabetes mellitus type two (T2DM) is one of the most extensive diseases in the world. Herbal therapy remains a possible adjunct therapy to sustain better glycemic control and reduce complications arising from diabetes. In order to evaluate the curative impacts of olive leaf extract (OLE) on streptozotocin (STZ)induced diabetic rats, twenty-four Wistar male adult rats were divided into four equal groups; control, diabetic control (45 mg/kg STZ), normal rats treated with OLE (17.8 mg/kg b.wt.), and diabetic rats treated with OLE $(45 \mathrm{mg} / \mathrm{kg} \mathrm{STZ}+17.8 \mathrm{mg} / \mathrm{kg}$ b.wt.). The OLE extract was investigated for in vitro antioxidant activity using the $\mathrm{DPPH}^{\bullet}$ assay. The phenolic, tannin, and flavonoid contents were determined. The activity of GPX, SOD, and GSH in RBC lysate, CAT in plasma and MDA in serum were measured. The OLE prevented the decrease in GSH and kept MDA around the normal range in the treated diabetic rats. The current study suggests that OLE might be used safely to ameliorate T2DM and its accompanying oxidative stress.
\end{abstract}

KEYWORDS: Antioxidant enzymes activity; Diabetes mellitus type two; Flavonoids; Olive leaves extract; Oxidative stress; Phenolics

RESUMEN: Acción de extractos de hojas de olivo sobre marcadores del estrés oxidativo en diabetes mellitus inducida por estreptozotocina en ratas. La diabetes mellitus tipo dos (DM2) es una de las enfermedades más extensas en el mundo. La terapia con hierbas sigue siendo una terapia complementaria para mantener un mejor control de la glucemia y reducir las complicaciones de la diabetes. Con el fin de evaluar los efectos curativos del extracto de hojas de olivo (OLE) en ratas diabéticas inducidas por estreptozotocina (STZ), veinticuatro ratas Wistar machos adultos se dividieron en cuatro grupos iguales; control, control diabético (45 mg/ kg STZ), ratas normales tratadas con OLE $(17.8 \mathrm{mg} / \mathrm{kg}$ b.wt) y ratas diabéticas tratadas con OLE (45 mg $/ \mathrm{kg} \mathrm{STZ} \mathrm{+}$ $17.8 \mathrm{mg} / \mathrm{kg}$ b.wt.). El extracto OLE se investigó para determinar la actividad antioxidante in vitro usando ensayos $\mathrm{DPPH}^{\bullet}$. Se determinaron los fenoles, los taninos y el contenido de flavonoides. Se midió la actividad de GPX, SOD y GSH en lisado de RBC, CAT en plasma y MDA en suero. El OLE evitó la disminución de GSH y mantuvo MDA alrededor del rango normal en las ratas diabéticas tratadas. El estudio actual sugiere que OLE podría utilizarse de forma segura para mejorar la DM2 y el estrés oxidativo que le acompaña.

PALABRAS CLAVE: Actividad de enzimas antioxidantes; Diabetes mellitus tipo dos; Estrés oxidativo; Extracto de hojas de olivo; Fenólicos Flavonoides

ORCID ID: Afify AMR https://orcid.org/0000-0001-8096-7649, El-Beltagi HS https://orcid.org/0000-0003-4433-2034, Fayed SA https://orcid.org/0000-0002-3449-6679, El-Ansary AE https://orcid.org/0000-0003-0585-1229

Citation/Cómo citar este artículo: Afify AMR, El-Beltagi HS, Fayed SA, El-Ansary AE. 2108. In vivo correlation of olive leaves extract on some oxidative stress markers in streptozotocin-induced diabetes mellitus in rats. Grasas Aceites 69 (1), e243. https://doi.org/10.3989/gya.1104172

Copyright: (C2018 CSIC. This is an open-access article distributed under the terms of the Creative Commons Attribution 4.0 International (CC BY 4.0) License. 


\section{INTRODUCTION}

Oxidative stress reflects an imbalance between free radical production and antioxidant defense mechanisms which results in the damaging of some molecules (El-Beltagi et al., 2017). Oxidative stress has been recorded to play a key role in the incidence and development of diabetes mellitus type two (T2DM) and consequently its complications. In diabetic subjects, disorders of the oxidative systems cause disequilibrium in endothelial function, which further causes inflammation (Ceriello et al., 2013). Oxidative stress plays a vital role during the progression of diabetic nephropathy (El-Beltagi et al., 2016). One of the risk elements in T2DM and its complications is oxidative stress. So, preventing oxidative stress could be an efficient way to assure an integrated management of T2DM (Adefegha and Oboh 2016). The causes which led to hyperglycemia can be linked to a metabolic stress situation and deficient glucose circulation in insulin-targetted tissues such as liver, adipose tissue and skeletal muscle (Hadrich et al., 2016).

Olive tree (Olea europaea L.) leaves have been broadly used in traditional therapy in European and Mediterranean countries as herbal teas, extracts, and powder. Olive leaf infusions and/or decoctions have been traditionally used to treat diabetes. The olive leaf has been recently accepted as a safe product in the category of food additives, permitted by the European Food Safety Authority (EFSA) (EFSA NDA Panel, 2014). Promising results associated with the valuable effects of olive leaf extract on health related to the high quantity of phenolic compounds might inspire the industry to consider the value of olive leaves as a source of antioxidants for the production of medicines, cosmetics, and nutraceuticals (Afify et al., 2017). Olive leaves were presented to be an abundant source of possibly valuable phytochemicals. Polyphenolic compounds play a key role in their biological effects. Olive leaf extract is a recognized source of oleuropein, its main efficient component that displayed various potential pharmaceutical properties such as antioxidant, antimutagen and anti-genotoxic characteristics (Hassen et al., 2015).

The aim of the current research was to reveal the effect of an aqueous extract of olive leaves on the oxidative status accompanying T2DM, and therefore decrease the harmful effects of oxidative stress which are responsible for diabetes complications.

\section{MATERIALS AND METHODS}

\subsection{Materials}

Streptozotocin was acquired from Sigma chemicals (St Louis, Mo, USA), at 97\% purity. All other reagents used were of analytical grade.

\subsection{Methods}

Preparation of olive aqueous extract. An aqueous extract of olive leaves was prepared by washing dry leaves and cutting them into small pieces with a blender. Olive leaf powder ( $25 \mathrm{~g})$ was soaked in $200 \mathrm{~mL}$ of distilled water and boiled for three minutes. The extract was collected and freeze dried on the same day; the fluid was about $195 \mathrm{~mL}$. The extract was redissolved in distilled wáter.

Diabetes induction. T2DM was induced by intraperitoneally injecting a single dose of STZ per body weight $(45 \mathrm{mg} / \mathrm{kg}$ b.wt.) dissolved in $0.01 \mathrm{M}$ citrate buffer ( $\mathrm{pH} 4.5)$ immediately before use. The rats had free access to food and water and were given a $5 \%$ glucose solution to drink overnight to encounter hypoglycaemic shock. The rats were checked daily for the presence of glycosuria. The rats were considered to be diabetic if glycosuria was present for 3 consecutive days. Three days after STZ injection, fasting blood samples were obtained and blood sugar was determined $(\geq 300 \mathrm{mg} / \mathrm{dL})$.

Animals. Twenty-four male Wistar rats $(120 \pm 10 \mathrm{~g})$ were purchased from the animal house of Helwan station for experimental animals, Helwan, Egypt. The rats were retained in polyethylene cages in groups of 6 rats per cage in a controlled environment $\left(25 \pm 2{ }^{\circ} \mathrm{C}, 50-60 \%\right.$ relative humidity and 12-hour light-dark cycle) for two weeks for adaptation. The rats were divided into four equal groups of 6 rats each. All experimental treatments were approved by Cairo University Ethics Committee for the Care and Use of Experimental Animals in Education and Scientific Research (CU-IACUC) and the approval number was CUIIS1616.

Experimental animal design. The animals were randomly allocated into four groups as follows:

Group 1: normal control.

Group 2: diabetic control (45 mg/kg STZ).

Group 3: normal rats treated with olive leaves extract (17.8 mg/kg b.wt.).

Group 4: diabetic rats treated with olive leafs extract $(17.8 \mathrm{mg} / \mathrm{kg}$ b.wt.). Olive leaf extract was dissolved in distilled water and then given by oral gavage administration five days a week during the study period (10 weeks). The dose was calculated as $20 \mathrm{mg}$ oleuropein/kg b.wt. Throughout this period, the rats were fed on a diet (TD.94045 AIN-93G Purified Diet) and water. The vitamin mix (AIN93-VX) (1\%) and mineral mix (AIN-93G-MX] $(3.5 \%)$.

Blood sample preparation. Blood samples were collected from the orbital sinus under anesthesia as follows: $\sim 3 \mathrm{~mL}$ in EDTA-coated tubes and $\sim 2 \mathrm{~mL}$ in plain tubes, centrifuged at $3000 \mathrm{rpm}$ for $10 \mathrm{~min}$ at $4{ }^{\circ} \mathrm{C}$ to get plasma and serum, respectively. The rats were sacrificed by cervical dislocation at the end of the study period. 


\subsection{Phytochemical compound determination}

\subsubsection{Determination of phenolic content}

Phenolic content was determined by using FolinCiocalteu reagent according to Ainsworth and Gillespie (2007). Briefly, $0.1 \mathrm{~mL}$ of sample aqueous extracts were added to $0.2 \mathrm{~mL}$ of $10 \%$ FolinCiocalteu reagent and vortexed thoroughly and then $0.8 \mathrm{~mL}$ of $\mathrm{Na}_{2} \mathrm{CO}_{3}(700 \mathrm{mM})$ were added into each tube and the assay tubes were incubated at room temperature for $2 \mathrm{~h}$ in the dark. Absorbance was measured at $765 \mathrm{~nm}$. Gallic acid was used as reference standard. Results were expressed as $\mathrm{mg}$ of gallic acid equivalents (GAE)/g dry weight.

\subsubsection{Determination of tannin content}

The tannins contents of olive leaf extract were measured by the Folin-Denis method according to Saxena et al., (2013). Accurately $0.5 \mathrm{~g}$ of the powdered olive leaf extract was moved to a $250 \mathrm{~mL}$ conical flask. Seventy-five $\mathrm{mL}$ water were added. The flask was heated gently and boiled for 30 min then centrifuged at $2000 \mathrm{rpm}$ for $20 \mathrm{~min}$. The supernatant was collected in a $100 \mathrm{~mL}$ volumetric flask and the volume was made up. One $\mathrm{mL}$ of the sample extract was transferred to a $100 \mathrm{~mL}$ volumetric flask containing $75 \mathrm{~mL}$ water. Five $\mathrm{mL}$ of Folin-Denis reagent were added; $10 \mathrm{~mL}$ of a $\mathrm{Na}_{2} \mathrm{CO}_{3}(700 \mathrm{mM})$ solution was diluted to $100 \mathrm{~mL}$ with water and shaken well. The absorbance was read at $700 \mathrm{~nm}$ after $30 \mathrm{~min}$. Tannic acid was used to prepare the standard curve. The color formed was determined at $500 \mathrm{~nm}$ using a Spectrophotometer. The results were expressed as $\mathrm{mg}$ of tannic acid equivalents (TAE)/g dry weight.

\subsubsection{Determination of flavonoids content}

Flavonoids were determined according to the method of Zhishen et al., (1999). Olive leaf extract $(0.4 \mathrm{~mL})$ was added to $4 \mathrm{~mL} \mathrm{H}_{2} \mathrm{O}$. Then $0.3 \mathrm{~mL} \mathrm{5 \%}$ $\mathrm{NaNO}_{2}$ were added. After $5 \mathrm{~min}, 0.3 \mathrm{~mL} 10 \% \mathrm{AlCl}_{3}$ were added. After six min, $2 \mathrm{~mL} \mathrm{NaOH}(1 \mathrm{M})$ were added and the total volume was made up to $10 \mathrm{~mL}$ with distilled water. The pink color was measured at $510 \mathrm{~nm}$ against a blank reagent using Spectrophotometer. Rutin was used to prepare the standard curve. Flavonoid content was calculated as $\mathrm{mg} / 100 \mathrm{~g}$ on a dry weight basis. The results were expressed as mg of rutin equivalents $(\mathrm{RuE}) / \mathrm{g}$ dry weight.

\subsection{Total antioxidant activity}

\subsubsection{DPPH free radical scavenging assay}

The antioxidant activity of olive leaf extract was determined according to the method reported by Brand-Williams et al., (1995). Briefly, $2.4 \mathrm{mg}$ of DPPH were dissolved in $100 \mathrm{~mL}$ methanol and $3.9 \mathrm{~mL}$ of this solution were added to $0.1 \mathrm{~mL}$ of olive leaf extract. The final concentration was $1.78 \mathrm{mg} / \mathrm{mL}$ and four dilutions were made; $1.424,1.068$ and $0.712 \mathrm{mg} / \mathrm{mL}$. The mixture was shaken vigorously and allowed to stand in the dark for $30 \mathrm{~min}$ at room temperature. Then the absorbance was measured at $515 \mathrm{~nm}$ using a T80 PG UV/VIS Spectrophotometer. Methanol was used as a blank to zero the spectrophotometer and $\mathrm{DPPH}^{\circ}$ was the control. DPPH ${ }^{\circ}$ free radical scavenging activity was expressed as the inhibition percentage and was calculated from the equation:

DPPH radical scavenging activity $(\%)=$

Absorbance of control - Absorbance of sample

Absorbance of control

Biochemical analysis. Blood samples were collected from orbital vinus under anesthesia as follows: $3 \mathrm{~mL}$ in EDTA-coated tubes and $2 \mathrm{~mL}$ in plain tubes, centrifuged at $3000 \mathrm{rpm}$ for $10 \mathrm{~min}$ at $4{ }^{\circ} \mathrm{C}$ to get plasma for CAT and serum for MDA and RBCs for GPX, SOD, and GSH analysis, respectively. The rats were sacrificed by cervical dislocation at the end of the study period.

\subsubsection{Determination of MDA (Malondialdehyde) activity}

The estimation of lipid peroxide is a colorimetric reaction with TBA (thiobarbituric acid) and was carried out as illustrated by Uchiyama and Mihara (1978), the measured lipid peroxide is calculated as malondialdehyde.

\subsubsection{Determination of GSH activity}

Reduced glutathione was estimated according to the method of Beutler et al., (1963).

\subsubsection{Determination of SOD activity}

Superoxide dismutase (SOD) was determined using the method of Nishikimi et al., (1972) as follows: the reaction mixture consists of $1.0 \mathrm{~mL}$ buffer ( $\mathrm{pH}$ 8.5), $0.1 \mathrm{~mL}$ nitroblue tetrazolium (NBT) and $0.1 \mathrm{~mL} \mathrm{NADH}$, mixed with $0.05 \mathrm{~mL}$ sample. The reaction was started by adding $0.01 \mathrm{~mL}$ phenazine methosulphate (PMS); then the increase in absorbance was read at wavelength $560 \mathrm{~nm}$ for five minutes.

\subsubsection{Determination of CAT activity}

Catalase activity (CAT) was determined using the method of Aebi (1983). The reaction mixture contained $0.05 \mathrm{~mL}$ sample, and $0.50 \mathrm{mLbuffer}(\mathrm{pH} 7.0)$. The reaction was initiated by adding $\mathrm{H}_{2} \mathrm{O}_{2}$, then the resulting color was read at wavelength $510 \mathrm{~nm}$. 


\subsubsection{Determination of GPX activity}

Briefly, $0.5 \mathrm{~mL}$ of supernatant, $0.2 \mathrm{~mL}$ of Tris buffer, $0.1 \mathrm{~mL}$ of sodium azide and $0.2 \mathrm{~mL}$ of ethylene diamine tetra acetic acid were mixed together. Then $0.2 \mathrm{~mL}$ of glutathione followed by $0.1 \mathrm{~mL}$ of $\mathrm{H}_{2} \mathrm{O}_{2}$ were added to the mixture. The tubes were shaken well and incubated at $37^{\circ} \mathrm{C}$ for 10 min beside a blank tube which contained all the reagents except the sample. The reaction was stopped after $10 \mathrm{~min}$ by adding $0.5 \mathrm{~mL}$ of $10 \% \mathrm{TCA}$. The tubes were centrifuged and the supernatant was used for the determination of glutathione.

\subsection{Statistical analysis}

Values are presented as means \pm SEM. Statistical analysis was carried out using the "costat" statistic computer program. Statistical analysis was based on One-way analysis of variance ANOVA followed by student-Newman Keuls test, and least significant difference (LSD) at $\mathrm{P}<0.05$. A Pearson product-moment correlation coefficient was used to describe the relationships between enzymatic and non-enzymatic antioxidants.

\section{RESULTS AND DISCUSSION}

\subsection{Phytochemical compound contents}

Table 1 shows that the content of tannins in olive leaf extract was $21.59 \pm 1.25 \mathrm{mg}$ TAE /g dry weight, while the phenolic content was $144.97 \pm 2.12 \mathrm{mg}$ GAE /g dry weight and flavonoid content was $143.01 \pm 2.52 \mathrm{mg} \mathrm{Ru} / \mathrm{g}$ dry weight. These results are consistent with the findings of Al-Marazeeq et al., (2016), who found that the total quantity of polyphenols in the water extract of olive leaves was $158 \mathrm{mg}$ GAE/g extract. However, the tannin content in our extract was much higher than reported by Al-Marazeeq et al., (2016), who found that the tannin content was $8 \mathrm{mg}$ GAE/g extract. The huge variance in tannins could be attributed to the cultivar difference. This explanation was supported by Brahmi et al., (2013) who found significant differences in tannins among two cultivars of olives, representing $8.10 \mathrm{mg} / \mathrm{g}$ dry weight in cv. Chemlali and $20.47 \mathrm{mg} / \mathrm{g}$ dry weight in cv. neb jmel.

At the same time, Sifaoui et al., (2014) found that phenolic compounds in different varieties of

TABLE 1. Phytochemical contents in olive leaves extract

\begin{tabular}{lc}
\hline Phytochemicals & Olive leaves extract \\
\hline Tannins (mg TAE/g dwt) & $21.59 \pm 1.25$ \\
Phenolics (mg GAE/g dwt) & $144.97 \pm 2.12$ \\
Flavonoids (mg RuE/g dwt) & $143.01 \pm 2.52$ \\
\hline
\end{tabular}

Values are represented as mean \pm SEM of triplicate determinations.
O. europaea leaves ranged from $46.809 \mathrm{mg} \mathrm{GAE} / \mathrm{g}$ to $153.917 \mathrm{mg} \mathrm{GAE} / \mathrm{g}$ of dry extract. The results found that flavenoid contents varied among species, in the range of 42.754 to $18.397 \mathrm{mg} \mathrm{RuE} / \mathrm{g}$ of dry extracts (Sifaoui et al., 2014). These findings are similar to those that reported by Stanković et al., (2017), who published that flavonoid content in the olive leaves from different cultivars varied between 52.40 and $129.39 \mathrm{mg}$ of RuE/g dry weight. Stanković et al., (2017) found that the phenolic content of $O$. europaea L. leaves from different cultivars was in the range of $127.18-314.69 \mathrm{mg}$ of GAE/g and they concluded that the differences in polyphenolic contents between olive leaf varieties could be due to varietal and ecological influences.

\subsection{DPPH free radical scavenging activity of olive leaf extract}

The antioxidant activity of olive leaf extract was measured using the DPPH method with four concentrations $0.712,1.068,1.424$ and $1.78 \mathrm{mg} /$ $\mathrm{mL}$ (Table 2). The results revealed that the antioxidant activity of olive leaf extract was significantly time and concentration dependent. While our olive leaf extract's antioxidant activity was $62.54 \%$ for $0.712 \mathrm{mg} / \mathrm{mL}$, Abaza et al., (2011) found that the antioxidant activity of the $0.5 \mathrm{mg} / \mathrm{mL}$ water olive leaf extract was $20.83 \%$.

The antioxidant effect of extracts on DPPH free radical scavenging may be due to their hydrogendonating capability, which decreases the stable olive leaf extract DPPH radical to the yellow DPPH-H. Antioxidants can capture the free radical chain of oxidation and form stable free radicals, avoiding further oxidation propagation (Xie et al., 2015). The phenolic compound content was highly correlated with DPPH antioxidant values, but moderate to weak correlation was found between the flavonoid content value and radical scavenging activity (Sifaoui et al., 2014). The reason for the antioxidant

TABLE 2. Antioxidant activity of olive leaves extract against DPPH free radical.

\begin{tabular}{lcl}
\hline Concentration (mg/mL) & \multicolumn{2}{c}{ Antioxidant activity (\%) } \\
\hline & $15 \mathrm{~min}$ & $30 \mathrm{~min}$ \\
0.712 & $57.46 \pm 0.025^{\mathrm{dB}}$ & $62.54 \pm 0.026^{\mathrm{dA}}$ \\
1.068 & $61.59 \pm 0.076^{\mathrm{cB}}$ & $66.14 \pm 0.234^{\mathrm{cA}}$ \\
1.424 & $65.98 \pm 0.025^{\mathrm{bB}}$ & $70.64 \pm 0.130^{\mathrm{bA}}$ \\
1.78 & $66.81 \pm 0.051^{\mathrm{aB}}$ & $71.54 \pm 0.026^{\mathrm{aA}}$ \\
LSD 0.05 & 0.16 & 0.44 \\
\hline
\end{tabular}

Values are represented as mean \pm SEM of triplicate determinations. The mean values with a different small letter within a column indicate significant differences $(\mathrm{p}<0.05)$. The mean values with a different capital letter within a row indicate significant differences $(\mathrm{p}<0.05)$. 
effect of olive leaf extract is the hydrolysis of oleuropein to hydroxytyrosol with the parallel increase in the antioxidant capacity of the extract and the synergistic effect of phenolic compounds in the olive leaf extract (Zafer and Filiz 2010).

Olive leaf extract showed marked antioxidant properties in the in vitro systems and exhibited a good bioavailability with $40 \%$ of the polyphenols being absorbed by the organism. These antioxidant properties were attributed to the phenolic metabolites that can preserve a strong antioxidant activity and show a significant antioxidant action in vivo (Martin-Vertedor et al., 2016). Moreover, Hayes et al., (2011) proved that OLE is able to scavenge free radicals at physiological $\mathrm{pH}$, therefore preventing the initiation and propagation of freeradical-mediated chain reactions which contribute to oxidative stress.

Martin-Vertedor et al., (2016) revealed that the most abundant compound in the olive leaf extract was oleuropein. In fact, oleuropein represented more than $50 \%$ of the total recognized compounds in olive leaves,followed by hydroxytyrosol, then many other phenolics (Charoenprasert and Mitchell, 2012). Oleuropein inhibitted the activities of free radicals and inhibitted oxidative stress in diabetic-induced rats (Qadir et al., 2016). The potent antioxidant activity of olive leaf extract could be attributed to its high total polyphenolic compound content, and oleuropein (Salah et al., 2012).

\subsection{Changes in MDA and GSH of normal and diabetic rats}

The results in Table 3 revealed a significant increase in the MDA serum level of diabetic rats as compared to normal control rats $(23.70 \pm 1.66$ $\mathrm{nmol} / \mathrm{mL}$ ). Diabetic rats received olive leaf extract decreased MDA formation in serum to the level of $15.07 \mathrm{nmol} / \mathrm{mL}$ and this decrease was significant when compared to the normal control group $(13.41 \mathrm{nmol} / \mathrm{mL})$. Table (3) shows the effect of olive leaf extract on GSH concentration in diabetic rats. The induction of diabetes resulted in a depletion of glutathione as shown in the diabetic control group $(8.22 \mathrm{mg} / \mathrm{dL})$ compared to normal control $(13.55 \mathrm{mg} / \mathrm{dL})$. However, the treatment of rats with olive leaf extract improved the GSH in diabetic rats treated with olive leaf extract $(14.33 \mathrm{mg} / \mathrm{dL})$.

A negative correlation was noticed between GSH and hyperglycemia, which means that rising serum glucose reduced the antioxidant capacity (Qadir et al., 2016). There is an inverse correlation which has been revealed among glucose level and enzymatic and non-enzymatic antioxidants (Qadir et al., 2016). The consumption oleuropein-rich olive leaf extract reduced plasma MDA levels in subjects, which was associated with higher plasma levels of metabolites derived from oleuropein (GarciaVillalba et al., 2014).

\subsection{Changes in SOD, CAT, and GPX of normal and diabetic rats}

Superoxide dismutase showed the lowest value $(27.7 \mathrm{U} / \mathrm{mL})$ in the diabetic control group (Table 4). Olive leaf extract improved SOD levels in the treated diabetic group $(31.40 \mathrm{U} / \mathrm{mL})$ to be near the value of the normal control $(35.9 \mathrm{U} / \mathrm{mL})$ and normal rats which were treated with olive leaf extract (36.40 U/mL) (Table 4).

In vivo effects of olive leaf extract on catalase levels in the plasma of rats were estimated. It was observed that the olive leaf extract exhibited a high level of catalase $(8.41 \mathrm{U} / \mathrm{mL})$ in the treated diabetic group compared to diabetic group and gave a value of $4.07 \mathrm{U} / \mathrm{mL}$. The normal treated group was also low with the value $7.62 \mathrm{U} / \mathrm{mL}$, but this decrease did not reach the statistically significant difference when correlated to the normal control 8.20 $\mathrm{U} / \mathrm{mL}$. The results presented in Table (4) indicate that diabetes induction affects the GPX level. As expected from the GSH results, the GPX level falls dramatically in the diabetic group $(907.82 \mathrm{U} / \mathrm{mL})$ when compared to normal control group (1469.81 $\mathrm{U} / \mathrm{mL}$ ). The olive leaf extract retrieved the GPX value in the treated diabetic group with a value of $1253.66 \mathrm{U} / \mathrm{mL}$. Exactly like the GSH results' trend, the normal rats that received olive leaf extract showed the highest GPX value $(1642.73 \mathrm{U} / \mathrm{mL})$,

TABLE 3. MDA in Serum and GSH in RBC lysate from normal, diabetic and treated groups.

\begin{tabular}{|c|c|c|c|c|}
\hline \multirow[b]{2}{*}{ Groups } & \multicolumn{2}{|c|}{ MDA (nmol/mL) } & \multicolumn{2}{|c|}{ GSH (mg/dL) } \\
\hline & Zero time & 10 wees & Zero time & 10 weeks \\
\hline Normal Control & $12.93 \pm 1.18^{\mathrm{aA}}$ & $13.41 \pm 0.73^{\mathrm{bA}}$ & $13.55 \pm 0.97^{\mathrm{aA}}$ & $13.55 \pm 0.59^{\mathrm{bA}}$ \\
\hline Diabetic Control & $12.43 \pm 1.14^{\mathrm{aB}}$ & $23.70 \pm 1.66^{\mathrm{aA}}$ & $13.78 \pm 0.80^{\mathrm{aA}}$ & $8.22 \pm 0.89^{\mathrm{cB}}$ \\
\hline Normal rats treated with OLE & $13.41 \pm 0.73^{\mathrm{aA}}$ & $12.10 \pm 0.85^{\mathrm{bA}}$ & $14.33 \pm 1.00^{\mathrm{aB}}$ & $18.66 \pm 1.15^{\mathrm{aA}}$ \\
\hline Diabetic rats treated with OLE & $12.10 \pm 0.85^{\mathrm{aA}}$ & $15.07 \pm 0.25^{\mathrm{bA}}$ & $13.00 \pm 0.33^{\mathrm{aA}}$ & $14.33 \pm 0.58^{\mathrm{bA}}$ \\
\hline LSD 0.05 & 4.55 & 3.29 & 3.49 & 2.73 \\
\hline
\end{tabular}

Values are mean \pm SEM. Each group contains 6 rats. The mean values with a different small letter within a column indicate significant differences $(\mathrm{p}<0.05)$. The mean values with a different capital letter within a row indicate significant differences $(\mathrm{p}<0.05)$. 
TABLE 4. Effect of aqueous extract of olive leaves on SOD in RBC lysate, CAT in plasma and GPX in RBC lysate levels from STZ-induced diabetic rats.

\begin{tabular}{|c|c|c|c|c|c|c|}
\hline \multirow[b]{2}{*}{ Groups } & \multicolumn{2}{|c|}{ SOD $(\mathrm{U} / \mathrm{mL})$} & \multicolumn{2}{|c|}{ CAT (U/mL) } & \multicolumn{2}{|c|}{ GPX (U/mL) } \\
\hline & Zero time & 10 weeks & Zero time & 10 weeks & Zero time & 10 weeks \\
\hline Normal Control & $36.2 \pm 0.2^{\mathrm{aA}}$ & $35.9 \pm 0.5^{\mathrm{aA}}$ & $8.04 \pm 0.33^{\mathrm{aA}}$ & $8.20 \pm 0.85^{\mathrm{aA}}$ & $1426.58 \pm 74.88^{\mathrm{aA}}$ & $1469.81 \pm 86.46^{\mathrm{aA}}$ \\
\hline Diabetic Control & $35.4 \pm 0.2^{\mathrm{aA}}$ & $27.7 \pm 2.7^{\mathrm{bB}}$ & $7.49 \pm 0.51^{\mathrm{aA}}$ & $4.07 \pm 0.36^{\mathrm{bB}}$ & $1556.27 \pm 149.75^{\mathrm{aA}}$ & $907.82 \pm 74.88^{\mathrm{cB}}$ \\
\hline Normal rats treated with OLE & $36.2 \pm 0.4^{\mathrm{aA}}$ & $36.4 \pm 0.1^{\mathrm{aA}}$ & $7.94 \pm 0.44^{\mathrm{aA}}$ & $7.62 \pm 0.41^{\mathrm{aA}}$ & $1491.43 \pm 64.84^{\mathrm{aA}}$ & $1642.73 \pm 86.00^{\mathrm{aA}}$ \\
\hline Diabetic rats treated with OLE & $35.2 \pm 0.1^{\mathrm{aA}}$ & $31.4 \pm 1.9^{\mathrm{abA}}$ & $7.46 \pm 0.48^{\mathrm{aA}}$ & $8.41 \pm 0.05^{\mathrm{aA}}$ & $1426.58 \pm 129.69^{\mathrm{aA}}$ & $1253.66 \pm 114.38^{\mathrm{bA}}$ \\
\hline LSD 0.05 & 0.97 & 5.47 & 1.68 & 1.64 & 464.85 & 299.06 \\
\hline
\end{tabular}

Values are mean \pm SEM. Each group contains 6 rats. The mean values with a different small letter within a column indicate significant differences $(p<0.05)$. The mean values with a different capital letter within a row indicate significant differences $(p<0.05)$.

significantly. The current findings are consistent with those reported by Park et al., (2013) who showed that the concentrations of SOD were lower in the diabetic group than in the control group. Though the SOD level in their olive leaf extracttreated diabetic group tended to rise compared with the diabetic group. Also, the plasma CAT level was higher in the olive leaf-supplemented group than in the diabetic group. In addition, GPX activity was lower in the diabetic group than in the normal control group; however, GPX activity in the olive leaf-supplemented group was significantly higher than that in the diabetic group (Park et al., 2013). The administration of olive leaf extract led to a reduction in the severe alterations of GSH and MDA in diabetic rats. These findings clearly showed that olive leaf extract plays a defensive role against oxidative stress damage in diabetic rats. In the Park et al., (2013) study, treatment with olive leaves relieved oxidative stress through the elevation of plasma antioxidant enzymes; SOD and CAT levels were significantly lower in the diabetic control group and greater in animals from the olive leaf supplemented group.

The GPX level also tracked a similar trend to that of SOD and CAT levels which increased in the diabetic olive leaf treated group. These results suggest that olive leaf extract prompted a protecting effect by inducing the scavenging of ROS, thus decreasing diabetes-related complications. The antioxidant effect of olive leaf extract could be clarified on the basis that olive leaf extract induced the protein synthesis of antioxidant enzymes (Salah et al., 2017).

Olive leaf extract has been ascribed with antioxidant, antihypertensive, hypoglycemic, hypocholesterolemic, anti-inflammatory, antiatherogenic, chemopreventive, anti-cancer properties and also against metabolic disorders (Bulotta et al., 2014). The present results showthat endogenous antioxidants such as CAT, SOD, and GPX decreased while, MDA levels increased, which revealed that oxidative stress was reinforced in STZ-diabetic rats.

\subsection{Pearson correlation between antioxidant parameters}

A Pearson product-moment correlation coefficient was computed to evaluate the relationship between different enzymatic and non-enzymatic antioxidant parameters. The results suggest that all the correlations were statistically significant.

The statistical analysis indicated that a strong negative correlation was found between both MDA and SOD ( $\mathrm{r} 2=0.62, \mathrm{p} \leq 0.05)$, and between MDA and GPX (r2 = 0.68, p $\leq 0.05)$ (Fig $1 \mathrm{~A}$ and B). In addition, a strong negative correlation was found between MDA and CAT ( $22=0.58, \mathrm{p} \leq 0.05)$ and between MDA and GSH ( $\mathrm{r} 2=0.57, \mathrm{p} \leq 0.05)($ Fig $1 \mathrm{C}$ and D). Park et al., (2013) also found a negative correlation between GSH and MDA. El-Beltagi et al., (2016) assumed that the depletion of GSH might be partly responsible for the elevated lipid peroxidation. On the other hand, a strong positive correlation was found between SOD and GPX (r2 $=0.53$, $\mathrm{p} \leq 0.05$ ) (Fig 2 A). Park et al., (2013) verified a positive correlation among SOD and GPX. However, a weak positive correlation takes place between SOD and CAT (r2 = 0.31, p $\leq 0.05)$ (Fig 2 B).

The present results demonstrated that olive leaf extract may have a direct promising application in the pharmaceutical field, due to the existence of bioactive compounds. Oleuropein and hydroxytyrosol, which are main polyphenolic constituents of olive leaves, restored the antioxidant distresses in diabetic rats. In the current study, it is difficult to make an overall assumption about structure-antioxidant activity relationships with the small number of antioxidant molecules under assessment. So, further research should be carried out to investigate the bioactive compounds in olive leaf extract which are responsible for its biological effects.

\section{CONCLUSIONS}

It could be concluded that Olive leaf extract had high antioxidant activity, and this activity was timeconcentration dependent. Olive leaf extract showed 
(a)
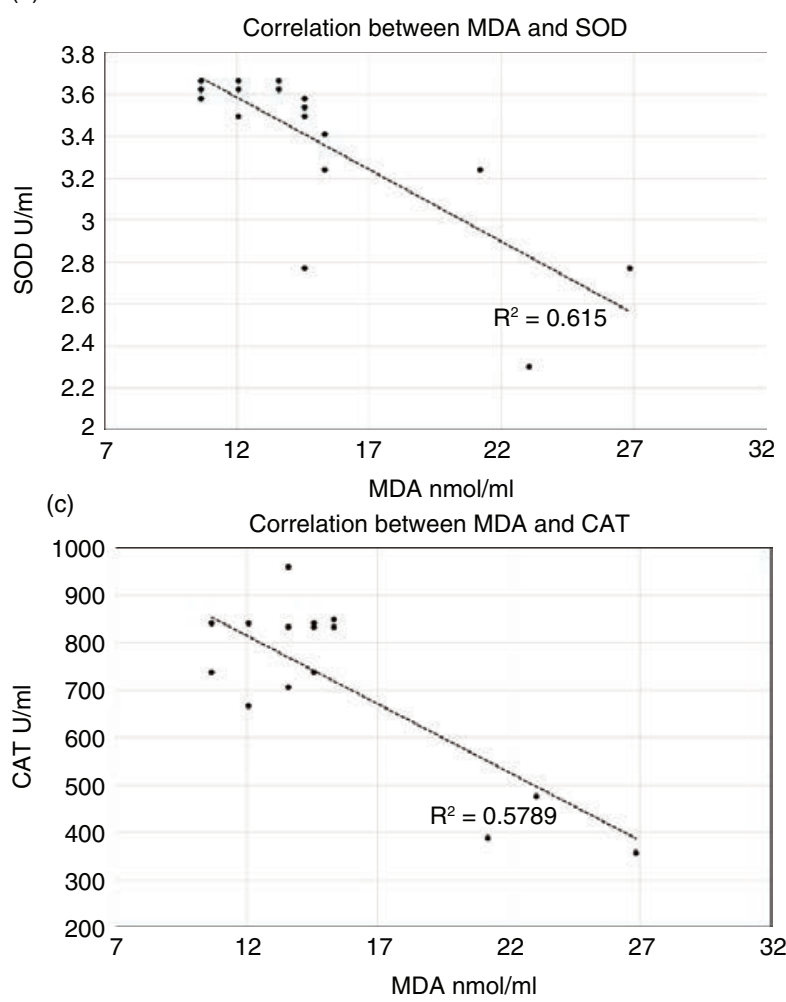

(b)
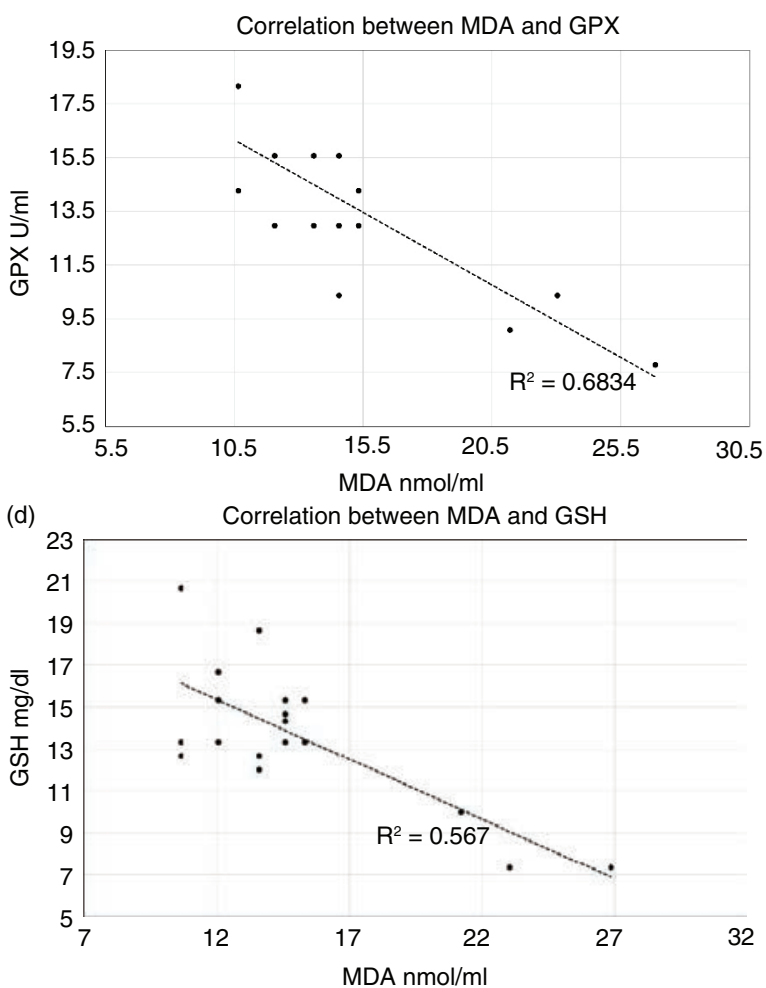

FIGURE 1. Correlation between: A. MDA (nmol/mL) and SOD (U/mL), B. MDA (nmol/mL) and GPX (U/mL), C. MDA (nmol/mL) and CAT (U/mL), D. MDA (nmol/mL) and GSH (mg/dL).

(a)

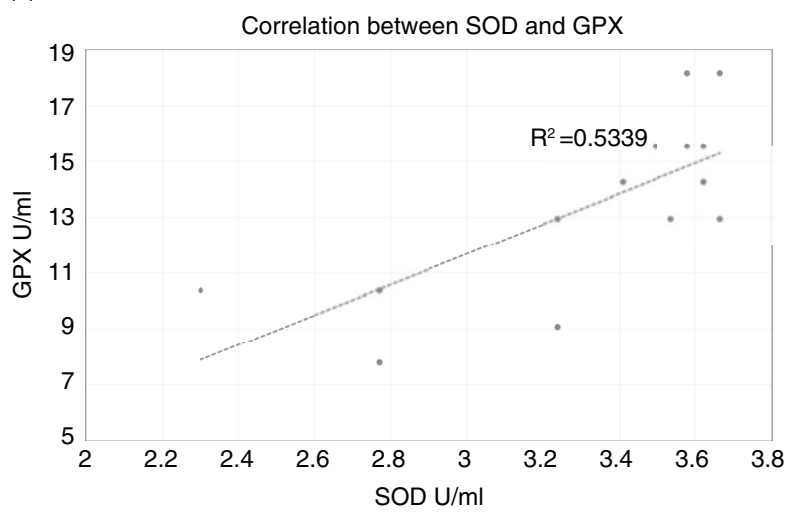

(b)

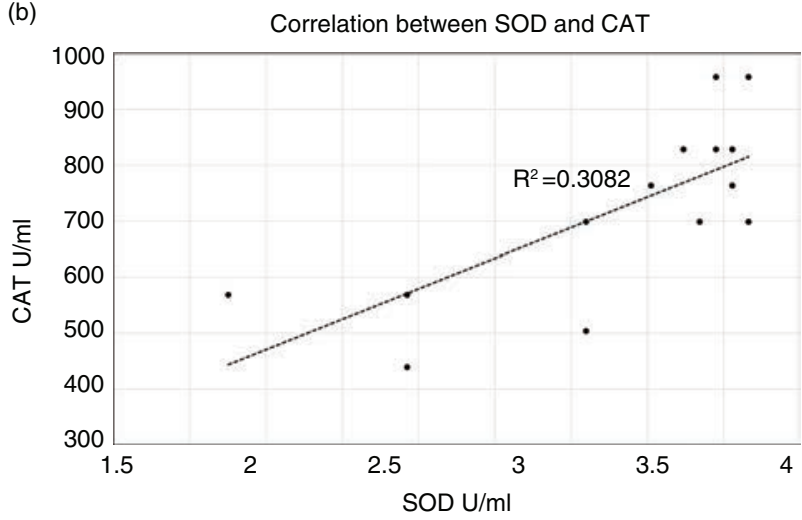

FIgURE 2. Correlation between: A. SOD $(\mathrm{U} / \mathrm{mL})$ and GPX $(\mathrm{U} / \mathrm{mL})$, B. SOD $(\mathrm{U} / \mathrm{mL})$ and CAT $(\mathrm{U} / \mathrm{mL})$.

a healing effect on the diabetic state by controlling oxidative stress in diabetic rats. Therefore, using olive leaf extract as a pharmaceutical product could be useful for diabetic individuals.

\section{ACKNOWLEDGMENTS}

The authors would like to show their appreciation to the Faculty of Agriculture, Cairo University, Department of Biochemistry, for continuing cooperation to support research that provided the facilities necessary to accomplish the most wanted objectives of this research.

\section{REFERENCES}

Abaza L, Youssef NB, Manai H, Haddada FM, Methenni K, Zarrouk M. 2011. Chétoui olive leaf extracts: influence of the solvent type on phenolics and antioxidant activities. Grasas Aceites 62, 96-104. https://doi.org/10.3989/ gya. 044710

Adefegha SA, Oboh G. 2016. Antioxidant and inhibitory properties of Clerodendrum volubile leaf extracts on key enzymes relevant to non-insulin dependent diabetes 
mellitus and hypertension. J. Taibah Univ. Med. Sci. 10, 521-533. https://doi.org/10.1016/j.jtusci.2015.10.008

Aebi H. 1984. Catalase in vitro. Methods in enzymology 105, $121-126$.

Ainsworth EA, Gillespie KM. 2007. Estimation of total phenolic content and other oxidation substrates in plant tissues using Folin-Ciocalteu reagent. Nat. Protoc. 2, 875-877. https://doi.org/10.1038/nprot.2007.102

Afify AMR, El-Beltagi HS, Fayed SA, El-Ansary AE. 2017. Hypoglycemic and iron status ameliorative effects of Olea europea CV.'Picual' leaves extract in streptozotocin induced diabetic rats. Fresen. Environ. Bull. 26, 6898-6908.

Al-Marazeeq K, Haddadin MSY, Abdulla B, Haddadin JS. 2016. Biological activities of olive leaves extract from nabali baladi variety against lipid and protein oxidation. Int J. Biol. Biotech. 13, 283-291.

Beutler E, Duran O, Kelly BM. 1963. Improved method for the determination of blood glutathione. J. Lab. Clin. Med. 61, 882-888.

Brahmi F, Mechri B, Flamini G, Dhibi M, Hammami M. 2013. Antioxidant activities of the volatile oils and methanol extracts from olive stems. Acta Physiologiae Plantarum 35, 1061-1070. https://doi.org/10.1007/s11738-012-1144-2

Brand-Williams W, Cuvelier ME, Berset CLWT. 1995. Use of a free radical method to evaluate antioxidant activity. LWT-Food Sci. Technol. 28, 25-30. https://doi.org/10.1016/ S0023-6438(95) 80008-5

Bulotta S, Celano M, Lepore SM, Montalcini T, Pujia A, Russo D. 2014. Beneficial effects of the olive oil phenolic components oleuropein and hydroxytyrosol: focus on protection against cardiovascular and metabolic diseases. J. Transl. Med. 12, 219. https://doi.org/10.1186/s12967-014-0219-9

Ceriello A, Novials A, Ortega E, Canivell S, Sala LL, Pujadas G, Bucciarelli L, Rondinelli, M, Genovese S. 2013. Vitamin $\mathrm{C}$ further improves the protective effect of glucagon-like peptide-1 on acute hypoglycemia-induced oxidative stress, inflammation, and endothelial dysfunction in type 1 diabetes. Diabetes Care 36, 4104 4108. https://doi.org/10.2337/ dc13-0750

Charoenprasert S, Mitchell A. 2012. Factors influencing phenolic compounds in table olives (Olea europaea). J. Agric. Food Chem. 60, 7081-7095. https://doi.org/10.1021/jf3017699

Efsa NDA. 2014. Panel (EFSA Panel on Dietetic Products, Nutrition and Allergies). Scientific Opinion on the substantiation of a health claim related to olive (Olea europaea $\mathrm{L}$.) leaf water extract and increase in glucose tolerance pursuant to Article 13(5) of Regulation (EC) No 1924/2006. EFSA J. 12, 3655. https://doi.org/10.2903/j.efsa.2014.3655

El-Beltagi HS, Abdel-Mobdy YE Abdel-Rahim E. 2017. Toxicological influences of cyfluthrin attenuated by Solenostemma argel extracts on carbohydrate metabolism of male albino rats. Fresen. Environ. Bull. 26, 1673-1681.

El-Beltagi HS, Ahmed OK. Hegazy AE. 2016. Protective effect of nitric oxide on high temperature induced oxidative stress in wheat. Not. Sci. Biol. 8, 192-198. https://doi. org/10.15835/nsb.8.2.9807

Hadrich F, Garcia M, Maalej A, Moldes M, Isoda H, Feve B Sayadi S. 2016. Oleuropein activated AMPK and induced insulin sensitivity in $\mathrm{C}_{2} \mathrm{C}_{12}$ muscle cells. Life Sci. 151, 167-173. https://doi.org/10.1016/j.lfs. 2016.02.027

Hassen I, Casabianca H, Hosni K. 2015. Biological activities of the natural antioxidant oleuropein: Exceeding the expectation-A mini-review. J. Funct. Foods. 18, 926-940. https:// doi.org/10.1016/j.jff.2014.09.001
Hayes JE, Allen P, Brunton N, O'grady MN, Kerry JP. 2011. Phenolic composition and in vitro antioxidant capacity of four commercial phytochemical products: Olive leaf extract (Olea europaea L.), lutein, sesamol and ellagic acid. Food Chem. 126, 948-955. https://doi.org/10.1016/j. foodchem.2010.11.092

Martín-Vertedor D, Garrido M, Pariente JA, Espino J, DelgadoAdámez J. 2016. Bioavailability of bioactive molecules from olive leaf extracts and its functional value. Phytother. Res. 30, 1172-1179. https://doi.org/10.1002/ptr.5625

Nishikimi M, Appaji N, Yagi K. 1972. The occurrence of superoxide anion in the reaction of reduced phenazinemethosulfate and molecular oxygen. Biochem. Biophys Res. Commun. 46, 849-854. https://doi.org/10.1016/S0006-291X(72)80218-3

Park JH, Jung JH, Yang JY, Kim HS. 2013. Olive leaf downregulates the oxidative stress and immune dysregulation in streptozotocin-induced diabetic mice. Nutr. Res. 33, 942-951. https://doi.org/10.1016/j.nutres.2013.07.011

Qadir NM, Ali KA, Qader SW. 2016. Antidiabetic effect of oleuropein from Olea Europaea leaf against alloxan induced type 1 diabetic in rats. Braz. Arch. Biol. Technol. 59, 1-10. https://doi.org/10.1590/1678-4324-2016150116

Rotruck JT, Pope AL, Ganther HE, Swanson AB, Hafeman DG, Hoekstra W. 1973. Selenium: biochemical role as a component of glutathione peroxidase. Science 179, (4073), 588-590. https://doi.org/10.1126/science.179.4073.588

Salah MB, Abdelmelek H, Abderraba M. 2012. Study of phenolic composition and biological activities assessment of olive leaves from different varieties grown in Tunisia. Med. Chem 2, 107-111.

Salah MB, Hafedh A, Manef A. 2017. Anti-diabetic activity and oxidative stress improvement of Tunisian Gerboui olive leaves extract on alloxan induced diabetic rats. J. Mater. 8 , 1359-1364. http://www.jmaterenvironsci.com/

Saxena V, Mishra G, Akash S, Vishwakarma KK. 2013. A comparative study on quantitative estimation of tannins in Terminalia chebula, Terminalia belerica, Terminalia arjuna and Saraca indica using spectrophotometer. Asian. J. Pharm. Clin. Res. 6, 148-149. https://innovareacademics.in/journals/ index.php/ajpcr/article/view/329/196

Sifaoui I, López-Arencibia A, Martín-Navarro CM, Chammem N, Reyes-Batlle M, Mejri M, Lorenzo-Morales J, Abderabba M, Piñero JE. 2014. Activity of olive leaf extracts against the promastigote stage of Leishmania species and their correlation with the antioxidant activity. Exp. Parasitol. 14, 106-111. https://doi.org/10.1016/j.exppara.2014.03.002

Stanković M. Ćurčić S, Zlatić N, Bojović B. 2017. Ecological variability of the phenolic compounds of Olea europaea L. leaves from natural habitats and cultivated conditions, Biotechnol. Biotec. Eq.. 31, 499-504. https://doi.org/10.108 $0 / 13102818.2016 .1275804$

Uchiyama M, Mihara M. 1978. Determination of malonaldehyde precursor in tissues by thiobarbituric acid test. Anal. Biochem. 86, 271-278. https://doi.org/10.1016/ 0003-2697(78)90342-1

Xie PJ, Huang LX, Zhang CH, Zhang YL. 2015. Phenolic compositions, and antioxidant performance of olive leaf and fruit (Olea europaea L.) extracts and their structure-activity relationships. J. Funct. Foods 16, 460-471. https://doi. org/10.1016/j.jff.2015.05.005

Zhishen J, Mengcheng T, Jianming W. 1999. The determination of flavonoid contents in mulberry and their scavenging effects on superoxide radicals. Food Chem. 64, 555-559. https://doi.org/10.1016/S0308-8146(98)00102-2 